\title{
ニホンジカ高密度生息地域のヒノキ人工林における 間伐後の表土移動に影響する要因
}

\section{島田博匡 $\left.{ }^{*} 1\right)$}

\author{
1）三重県林業研究所
}

摘要: ニホンジカ高密度生息地域におけるヒノキ人工林に間伐区 と無間伐区を設け, 土砂受け箱法により間伐後の表土移動量 (細 土，土砂，リター）を比較することで, シ力高密度生息地域にお ける表土移動に及ぼす間伐, 地表面被覆, 傾斜の影響を検討した。 間伐区の表土移動量は無間伐区よりも少なかったが, 間伐後に地 表面の植生被覆率は増加していなかった。一般化線形混合モデル による解析の結果, 各土砂受け箱の表土移動量は地表面の植生被 覆率, リター被覆率, 石碩被覆率と関係していたが, シ力採食の 影響を受けた人工林では間伐有無に関わらず植生被覆率が低い ことから,リターと石䃭の被覆率が表土移動量を決定していた。 キーワード : 土砂受け箱, 侵食防止, 地表面被覆, 下層植生, シ 力, 三重県

\section{1. はじめに}

森林が有する表土流出防止機能に果たす下層植生による地 表面被覆の役割は大きい 2,9$)$ 。人林では間伐により光環境 を改善し，下層植生を導入することで表土移動量が減少する ことが報告されている 1,14)。しかし，近年ではニホンジカ

(Cervus nippon Temm. , 以後, シカとする) の個体数増 加により, 人工林で間伐を行ってもシカ採食により木本種の 更新が阻害される事例 17)が報告されている。このことから, シ力高密度生息地域では表土保全に対する間伐の効果が得ら れない可能性があると考えられるが，これまでにシカ高密度 生息地域における人工林で間伐後の表土移動を調査し, シカ の影響を明らかにした事例はみられない。そこで本研究では シ力高密度生息地域におけるヒノキ人工林に間伐区と無間伐 区を設け，間伐後の表土移動量を比較することで間伐の効果 とシカの影響を明らかにするとともに，間伐後の表土移動に 影響を及ぼす要因を検討した。

\section{2. 調查地と方法}

調査は三重県多気郡大台町 (旧宮川村) の標高 530～650 m にある北向き斜面の $46 \sim 50$ 年生（2002 年時点）ヒノキ人工 林において行った。メッシュ気候值 $\left.2000^{8}\right)$ にると調查地付
近の年平均気温は $11.6{ }^{\circ} \mathrm{C}$, 暖かさの指数は 88.4, 年間降水 量は $2,726.6 \mathrm{~mm}$ であった。地質は三波川変成岩類, 土猿型 は適潤性褐色森林土（偏乾亜型） $\mathrm{B}$ (d) である。調査地付近で はシカ生息密度が高く, 2004 年に糞粒法により推定された生 息密度は調査地から約 $5 \mathrm{~km}$ 離れた箇所で 19.1 頭 $/ \mathrm{km}^{2}$ であ り 10), 自然植生にあまり目立った影響が出ない密度 6)とされ る 3〜5 頭 $/ \mathrm{km}^{2}$ を超えている。

調査地内に $20 \mathrm{~m} \times 20 \mathrm{~m}$ の調査区を, 標高 $600 \sim 650 \mathrm{~m}$ 付 近の斜面上部（調查区 No.1，2）と標高 530 550 m 付近の 斜面下部（調査区 No.3，4）の平衡斜面に 2 箇所ずつ設置し た（表-1）。調查区 No.1 と No.4 は間伐区とし（以後，それ ぞれ No.1 間伐区, No.4 間伐区とする), 2002 年 12 月〜2003 年 1 月にかけて, 調査区内とその周囲 $10 \mathrm{~m}$ 程度において本 数率 $50 \%$, 材積率 $40 \%$ 程度の間伐を実施した。間伐木は現 地に切り捨てた。調查区 No.2 およびNo.3については無間伐 区とし（以後，それぞれNo.2 無間伐区，No.3 無間伐区とす る），間伐を行わずにそのまま放置した。この試験地におけ る光環境，下層植生の植被率の間伐前から間伐後 2 年間の変 化については既に報告されている ${ }^{15)}$ 。各調査区内に $2 \mathrm{~m} \times 2$ $\mathrm{m}$ の調査枠を 4 力所設置し, その中央で撮影した地上 $1.2 \mathrm{~m}$ 高の全天空写真から LIA for Win3218)によって理論的に相対 照度と同義とされる Sky Factor ${ }^{3)}$ 求めたところ, 間伐前の 2002 年 11 月にはいずれの調査地も 4 前後であったが, No.1 間伐区と No.4 間伐区では間伐後の 2003 年 6 月にそれぞれ 21.5，19.2まで上昇した。その後は漸減して 2004 年 11 月に

表-1 調査区の概況

\begin{tabular}{|c|c|c|c|c|c|c|c|c|c|}
\hline & & 間 & 伐 & 前 & 間 & 伐 & 後 & \multicolumn{2}{|c|}{ 間伐率 } \\
\hline 調 査 区 & $\begin{array}{l}\text { 林齢 } \\
\text { (年) }\end{array}$ & $\begin{array}{c}\text { 立木 } \\
\text { 密度 } \\
\text { (本/ha) }\end{array}$ & $\begin{array}{c}\text { 平均 } \\
\text { 樹高 } \\
\text { (m) }\end{array}$ & $\begin{array}{c}\text { 平均 } \\
\text { DBH } \\
(\mathrm{m})\end{array}$ & $\begin{array}{c}\text { 立木 } \\
\text { 密度 } \\
\text { (本/ha) }\end{array}$ & $\begin{array}{c}\text { 平均 } \\
\text { 樹高 } \\
\text { (m) }\end{array}$ & $\begin{array}{c}\text { 平均 } \\
\text { DBH } \\
(\mathrm{m})\end{array}$ & $\begin{array}{l}\text { 本数 } \\
(\%)\end{array}$ & $\begin{array}{l}\text { 材積 } \\
(\%)\end{array}$ \\
\hline NO.1 間伐区 & 46 & 1325 & 15.2 & 23.1 & 650 & 15.4 & 25.3 & 50.9 & 41.8 \\
\hline NO.2 無間伐区 & 46 & 1150 & 18.2 & 25.7 & - & - & - & - & - \\
\hline NO.3 無間伐区 & 50 & 950 & 16.9 & 26.5 & - & - & - & - & - \\
\hline NO.4 間伐区 & 50 & 1175 & 16.7 & 24.7 & 625 & 16.9 & 26.7 & 46.8 & 38.0 \\
\hline
\end{tabular}

* 連絡先著者 (Corresponding author) ：`515-2602 三重県津市白山町二本木 3769-1 E-mail : shimah03@pref.mie.jp 
はそれぞれ $14.7,14.2$ となった ${ }^{15)}$ 。また，調査枠内の全植 被率（\%) は調査期間を通して No.2 無間伐区 $>$ No.1 間伐区 $>$ No.3 無間伐区 $>$ No.4 間伐区の順に大きく，斜面上部，下 部ともに無間伐区で高かった 15)。No.2 無間伐区では 2002 年 11 月，2003 年 10 月ともに $9 \%$ 程度であったが，2004 年 11 月には約 $13 \%$ \%増加した。No.1 間伐区では間伐前の 2002 年 11 月には約 $7 \%$ であったが，間伐後の 2003 年 10 月以降 は少し低下して $5 \%$ 程度で推移した。No.3 無間伐区はほとん ど変化せず 3〜 $4 \%$ で横ばい傾向であった。No.4 間伐区は間 伐前後ともに $1 \%$ 前後であった。このように間伐, 無間伐に 関わらず，いずれの調查区においても植被率が低く，間伐後 に光環境が改善したにも関わらずほとんど増加しなかったこ とにはシカによる採食害の影響が示唆されている ${ }^{15)}$ 。

この調査区における表土移動量の測定には土砂受け箱法 5) を用いた。土砂受け箱は, 内寸が幅 $25 \mathrm{~cm} \times$ 高さ $15 \mathrm{~cm}$, 奥 行き $20 \mathrm{~cm}$ の木製箱で背面には水が抜けるように 30 メッシ ユのネットを貼り付け, 受け口の下辺には接地部の土が箱の 下へ抜けないようにブリキ製エプロン板を垂直下方に $5 \mathrm{~cm}$ 張り出すように取り付けたものである。2003 年 3 月に土砂 受け箱を各調査区の下端に，ほぼ等間隔に 10 個ずつ設置し た。土砂受け箱の直上の $5 \mathrm{~m}$ (水平距離) の範囲内は均一な 状態になるよう間伐木を全て除去した。表土移動量の調查は 2003 年 5 月 10 日から開始し， 2004 年 9 月 4 日までの 487 日間, 2004 年 3 月を除いて毎月 1 回土砂受け箱内に捕捉さ れた内容物を回収した。回収した内容物は風乾後, 細土（2 $\mathrm{mm}$ 未満), 碟 $(2 \mathrm{~mm}$ 以上 $)$, リターに区分し, $80{ }^{\circ} \mathrm{Cで}$ 48 時間乾燥したのち重量を測定した。本稿では，これらのう ち細土と碟を合わせて土砂とする。

表土移動量の評価には, 物質移動量と物質移動レートを用 いた ${ }^{12,13)}$ 。物質移動量（ $\left.\mathrm{g} \mathrm{m}^{-1}\right)$ は，各回収期間内に等高線 上の幅 $1 \mathrm{~m}$ を通過した物質の重量である。土砂受け箱の幅が $25 \mathrm{~cm}$ であるため, 測定された乾燥重量を 4 倍して物質移動 量とした。物質移動レート $\left(\mathrm{g} \mathrm{m}^{-1} \mathrm{~mm}^{-1}\right)$ は降水量 $1 \mathrm{~mm}$ あ たりの物質移動量で, 物質移動量を回収期間内の降水量

(mm) で除した值である。降水量は調査地から約 $3 \mathrm{~km}$ 北 西方向に位置する三重県県土整備部の明豆雨量観測所の日降 水量のデータを使用した。

地表面の被覆状況を把握するため，2003 年 12 月 9 日に, 各調查区の全ての土砂受け箱直上部に $0.5 \mathrm{~m} \times 0.5 \mathrm{~m}$ の調査
枠を置き, 枠内の植生（地上高 $0.5 \mathrm{~m}$ 以下）, リター, 直径 $2 \mathrm{~cm}$ 以上の石礫について, それぞれの被覆率（\%) を目視に より測定した。このとき植生では, 草本種には既に地上部が 枯れているものもみられたが，調査枠内ではこれらの植物は ほとんど侵入していなかった。落葉種のうちコガクウツギ

(Hydrangea luteo-venosa Koidz.) は大半落葉していたが, 葉が着いた状態を推測して被覆率を測定した。また，このと き同時に土砂受け箱直上 $0.5 \mathrm{~m}$ の傾斜 $\left(^{\circ}\right)$ を勾配定規で測 定した。

\section{3. 結果と考察}

3.1 調査区間の物質移動量と物質移動レートの比較

各調査区に設置した 10 個の土砂受け箱における調査期間 中の移動量合計（調查期間移動量）と調査期間移動量を調查 期間中の総雨量で除することで求めた調査期間移動レートに ついて表-2 に示す。細土, 土砂では, 調査期間移動量, 調査 期間移動レートともに無間伐区が間伐区よりも多い傾向がみ られ，No.3 無間伐区 $>$ No.2 無間伐区 $>$ No.1 間伐区 $>$ No.4 間伐区の順に大きく, 斜面下部の No.3 無間伐区と No.4 間伐 区の間に有意差がみられた（Holm の多重比較， $p<0.05 ） 。$ リターでは調査期間移動量, 調査期間移動レートともにNo.1 間伐区 $>$ No.3 無間伐区 $\fallingdotseq N o .2$ 無間伐区 $>$ No.4 間伐区の順で あり，No.1 間伐区が他の調査区よりも有意に大きかった (Holm の多重比較, $p<0.05$ )。

各調査区における細土, 土砂, リター移動レートの経時変 化を図-1 に示す。細土はいずれの調査区もほぼ同調して変化 し, 2003 年 5 月の調査開始後, 夏期に増加し, そこから冬 期にかけて減少したのち, 2004 年夏期に再び増加する傾向が みられた。土砂でも細土の経時変化とほぼ同様であったが, 2004 年 1 月と 4 月に一時的に大きな増加がみられた。また, 調査区間の比較では, 細土, 土砂ともに調査期間全体を通し て, 概ね No.3 無間伐区 $>$ No.2 無間伐区 $>$ No.1 間伐区 $>$ No.4 間伐区の順で移動レートが大きく, 調查期間移動量と同様に 無間伐区で多かった。リターについては, いずれの調査区も 調査開始からほぼ横ばいであったが，2003 年 12 月に大きく 増加し, その後 2004 年 8 月の調査終了まで徐々に減少する 傾向がみられた。調査区間の比較では明確な傾向はみられな かったが，No.4 間伐区では調査期間通して，他試験区よりも 少なめに推移した。

表-2 調査期間中の物質移動量と物質移動レート

\begin{tabular}{|c|c|c|c|c|c|c|c|c|c|c|c|c|c|c|c|}
\hline \multirow{2}{*}{\multicolumn{2}{|c|}{ 調査区 }} & \multirow{2}{*}{$\begin{array}{l}\text { 調査 } \\
\text { 日数 }\end{array}$} & \multirow{2}{*}{$\begin{array}{c}\text { 総雨量 } \\
(\mathrm{mm})\end{array}$} & \multicolumn{6}{|c|}{ 調查期間移動量 $\left(\mathrm{g} \mathrm{m}^{-1}\right)$} & \multicolumn{6}{|c|}{ 調查期間移動レート $\left(\mathrm{g} \mathrm{m}^{-1} \mathrm{~mm}^{-1}\right)$} \\
\hline & & & & \multicolumn{2}{|c|}{ 細土 } & \multicolumn{2}{|r|}{ 土砂 } & \multicolumn{2}{|c|}{ リター } & \multicolumn{2}{|r|}{ 細土 } & \multicolumn{2}{|c|}{ 土砂 } & \multicolumn{2}{|c|}{ リター } \\
\hline No.1 & 間伐区 & 487 & 4565 & 1530.66 & $(412.23) \mathrm{ab}$ & 2712.41 & $(748.75) \mathrm{a}$ & 474.58 & $(77.98)$ a & 0.34 & $(0.09) a b$ & 0.59 & $(0.16) \mathrm{a}$ & 0.10 & $(0.02) \mathrm{a}$ \\
\hline No. 2 & 無間伐区 & 487 & 4565 & 1605.64 & $(422.54) \mathrm{ab}$ & 3035.23 & $(741.88) \mathrm{ab}$ & 273.65 & $(55.43) \mathrm{b}$ & 0.35 & $(0.09) \mathrm{ab}$ & 0.66 & $(0.16) a b$ & 0.06 & $(0.01) \mathrm{b}$ \\
\hline No.3 & 無間伐区 & 487 & 4565 & 2748.16 & $(566.42)$ a & 5918.59 & $(1139.29) \mathrm{b}$ & 275.18 & $(42.71) \mathrm{b}$ & 0.60 & $(0.12)$ a & 1.30 & $(0.25) \mathrm{b}$ & 0.06 & $(0.01) \mathrm{b}$ \\
\hline No.4 & 間伐区 & 487 & 4565 & 1045.05 & $(230.83) \mathrm{b}$ & 1618.54 & $(457.97) \mathrm{a}$ & 229.28 & $(26.06) \mathrm{b}$ & 0.23 & $(0.05) \mathrm{b}$ & 0.35 & $(0.10) \mathrm{a}$ & 0.05 & $(0.01) \mathrm{b}$ \\
\hline
\end{tabular}

※括弧内の数值は標準誤差。

※ 異なるアルファベット間には有意差がある(Holmの多重比較, $p<0.05)$ 。 

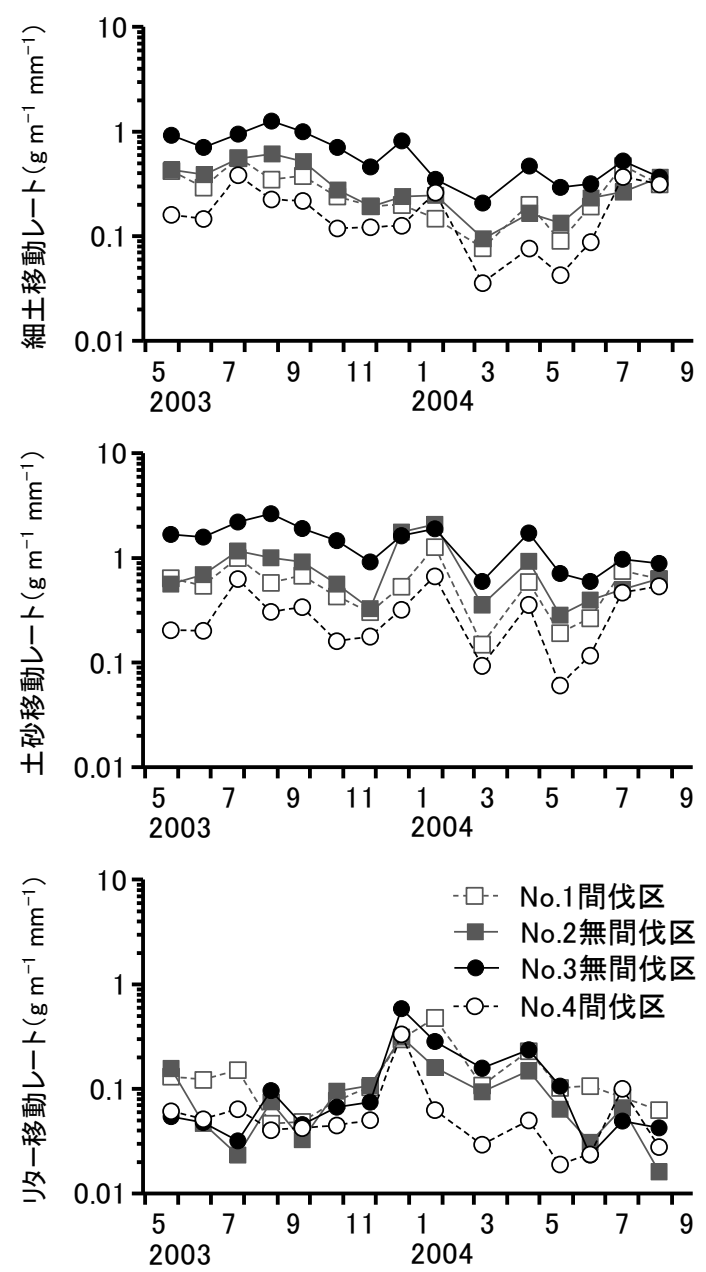

図-1＼cjkstart細土，土砂およびリター移動レートの経時変化

表-3 に各調查区の土砂受け箱直上の傾斜と地表面の被覆 率を示す。傾斜は，細土や土砂の調査期間移動量や調査期間 移動レートと同様に No.3 無間伐区 $>$ No.2 無間伐区 $>$ No.1 間伐区 $>$ No.4 間伐区の順で大きかった。斜面上部の No.1 間 伐区と No.2 無間伐区は，それぞれ $26.0^{\circ} ， 27.1^{\circ}$ でほとん ど差異がみられなかったが，斜面下部の No.3 無間伐区と No.4 間伐区はそれぞれ $31.3^{\circ}$ と $22.0^{\circ}$ で両者間には有意差

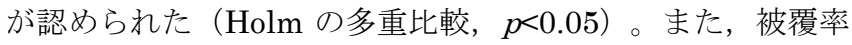
について，植生被覆率は $0.2 \sim 12.3 \%$ といずれの調査区でも 低く, No.2 無間伐区で最も大きかったが調查区間で有意差は みられなかった。本調查地で間伐有無に関わらず植被率が低 いことにはシカ採食の影響が示唆されている ${ }^{15)}$ 。リター被覆 率については 8.8〜 39.0\%であり，No.4 間伐区で最も高く， 他の調査区との間に有意差がみられた（Holm の多重比較， $p<0.05 ）$ 。石磼被覆率は 1.7〜 16.7\%であり，No.1 間伐区で 最も大きかったが，調査区間で有意差はみられなかった。

細土，土砂に関して，調查期間移動量，調查期間移動レー ト，移動レートの経時変化ともに，無間伐区が間伐区よりも 大きい結果となった（表-2, 図-1）。間伐により, 下層植生
表-3 土砂受け箱直上部の傾斜と地表面の被覆率

\begin{tabular}{|c|c|c|c|c|c|c|c|c|c|}
\hline \multirow{2}{*}{\multicolumn{2}{|c|}{ 調査区 }} & \multirow{2}{*}{\multicolumn{2}{|c|}{$\begin{array}{l}\text { 傾斜 } \\
\left({ }^{\circ}\right)\end{array}$}} & \multicolumn{6}{|c|}{ 被覆率 (\%) } \\
\hline & & & & \multicolumn{2}{|c|}{ 植生 } & \multicolumn{2}{|c|}{ リター } & \multicolumn{2}{|c|}{$\begin{array}{c}\text { 石㗂 } \\
\text { (径 } 2 \mathrm{~cm} \text { 以上) } \\
\end{array}$} \\
\hline No.1 & 間伐区 & 26.0 & (1.3) ab & 0.2 & $(0.1) \mathrm{a}$ & 8.8 & $(1.8) \mathrm{a}$ & 16.7 & $(6.8)$ a \\
\hline No. 2 & 無間伐区 & 27.1 & (1.4) ab & 12.3 & (8.6) a & 14.3 & $(2.7) \mathrm{a}$ & 1.7 & $(0.7) \mathrm{a}$ \\
\hline No. 3 & 無間伐区 & 31.3 & $(0.9)$ a & 0.3 & $(0.2) \mathrm{a}$ & 9.2 & $(2.0) \mathrm{a}$ & 5.7 & (1.6) a \\
\hline No.4 & 間伐区 & 22.0 & $(1.7) \mathrm{b}$ & 0.2 & $(0.1) \mathrm{a}$ & 39.0 & $(8.2) \mathrm{b}$ & 10.6 & $(4.2) \mathrm{a}$ \\
\hline
\end{tabular}

の増加に伴って表土移動が減少する 11 14)ことが報告されてい るが，本試験地では，間伐の有無に関わらず，いずれの調査 区でも土砂受け箱直上部の植生被覆率が低いことや（表-3）, 各調査区内に設置した 4 力所の調査枠内においても間伐によ る植被率の増加はみられず, 調查期間通して植被率が低かっ たように ${ }^{15)}$ ，間伐区の植被の状態に無間伐区と差異がみられ なかった。また，各調查区の細土や土砂の移動レートの経時 変化がほぼ同調し，間伐区で減少傾向がみられることもなか った（図-1）。これらのことから，本試験地において，間伐 実施の有無は無間伐区と間伐区の間にみられた移動量の差異 に寄与していないと考えられる。細土や土砂の調査期間移動 量や移動レートが最大であった No.3 無間伐区は傾斜が大き く, リターや石磎の被覆率が低い。最少であった No.4 間伐 区では傾斜が小さく, リターや石硯の被覆率が高かった（表 -3）。表土流亡は地表面被覆によって抑制できることが知ら れているが 2,11) , シカ採食の影響で植生の被覆がほとんど無 い本試験地では植生以外のリターや石碟などの被覆, 傾斜な どの要因が関係している可能性がある。

\section{2 表土移動に影響する要因}

表土移動に影響を及ぼす要因を明らかにするために，土砂 受け箱単位で目的変数を各土砂受け箱の調查期間移動レー 卜, 説明変数を各土砂受け箱直上部の植生被覆率, リター被 覆率，石㗂被覆率，傾斜，間伐有無，ランダム効果を調査区 として, 一般化線形混合モデル（GLMM）による解析を行っ た。誤差構造はガンマ分布, リンク関数は逆数とした。解析 には R version3.2.2 の glmer 関数を使用し，尤度の計算は Gauss-Hermite 近似によった。また, Dredge 関数を使用し てモデル選択を行い，AIC が最小のモデルを採用した。

解析の結果を表-4 に示寸。リターでは明確なモデルが得ら れなかったが, 細土，土砂では植生被覆率，リター被覆率， 石磪被覆率が変数に選択された。いずれも係数は正值をとり， リンク関数が逆数であることから被覆率が大きくなるほど調 查期間移動レートが低くなり，保全効果を発揮する傾向があ ることがわかった。傾斜, 間伐有無は変数として選択されな かった。森林において傾斜が大きいほど表土侵食量が増加す るものの ${ }^{9}$, 侵食量の多少に影響する順位はリター被覆割合, 降雨強度，傾斜の順であることが示されているが 7)，本研究 においても地表面被覆の影響が大きいことが明らかになっ た。また，選択された変数はすべて被覆率（\%) であり，係 
表-4 各土砂受け箱の調查期間移動レートに影響寸る要因. 一般化線形混合モデルの解析結果から AIC が最小のモデルにおける パラメータ值を示す.

\begin{tabular}{|c|c|c|c|c|c|c|c|}
\hline 区分 & $\mathrm{AIC}$ & $\begin{array}{c}\text { 植生被覆率 } \\
(\%) \text { ) }\end{array}$ & $\begin{array}{c}\text { リター被覆率 } \\
(\%)\end{array}$ & $\begin{array}{c}\text { 石礫被覆率 } \\
(\%)\end{array}$ & $\begin{array}{l}\text { 傾斜 } \\
\left({ }^{\circ}\right)\end{array}$ & 間伐有無 & 切片 \\
\hline 細土 & 26.9 & $0.210(0.179)$ & $0.107(0.047)^{*}$ & $0.104(0.063)$ & - & - & $0.666(0.556)$ \\
\hline 土砂 & 28.7 & $0.097(0.086)$ & $0.065(0.026)^{*}$ & $0.056(0.033)$ & - & - & $0.277(0.284)$ \\
\hline リター & 18.9 & - & - & - & - & - & $14.577(2.305)^{* * *}$ \\
\hline
\end{tabular}

$※ *: p<0.05, * *: p<0.01, * * *: p<0.001$

※ 一はモデル選択により変数に選択されなかったもの。

※ 括弧内の数值は標準誤差。

数の大きさから各変数の重要度を判断できるが，植生被覆率 の係数が最も大きく，植生被覆による表土保全効果が重要で ある可能性が示唆された。しかし，本調查地ではシカ採食の 影響を受けて，いずれの調査区でも植生被覆率が小さいこと から，リターと石碷の被覆率が表土保全効果を発揮している と考えられた。

\section{4. おわりに}

ヒノキ人工林の表土移動量は地表面の被覆状態により決定 されていた。シカ高密度生息地域でシカ採食の影響を受けた 人工林においては, 間伐の有無に関わらず植生被覆率が低い ことから, リターと石礫の被覆率が表土移動量に関係してお り, 間伐の効果はみられなかった。シ力高密度生息地域であ っても，気候や立地条件によっては間伐後にシカ不啫好性植 物のウラジロ (Gleichenia japonica Spr.)， イワヒメワラビ

(Hypolepis punctata (Thunb.) Mett. ex. Kuhn) などが繁 茂し4,16)，これらが地表を覆うことで表土の移動を防ぐ可能 性もあるが, 植生の侵入が期待できない場所では, 切り捨て 間伐木や未搬出材を等高線方向に横に並べること 19 )などに より，表土移動の低減を図る必要がある。

\section{引用文献}

1）荒木 誠・阿部和時（2005）間伐は森林の土壌を守れる か?. 森林科学, 44: 26-31.

2）池田英史・若松孝志・中屋 耕 ・ 阿部聖哉（2012）森林流 域からの土壤流出の実態・支配因子と予測モデル開発の現 状と課題. 水文・水資源学会誌, 25(6): 396-409.

3) Inoue, A., Okamura, A., Mizoue, N., Teraoka, Y. , Imada, M. (1996) Estimation of relative illuminance in forests using hemispherical photographs. Journal of Forest Planning, 2(2): 125-129.

4）石田弘明・服部 保 - 小涻誓治・黒田有寿茂・澤田佳宏 松村俊和・藤木大介 (2008) ニホンジカの強度採食下に発 達するイワヒメワラビ群落の生態的特性とその緑化への応 用. 保全生態学研究, 13(2): 137-150.

5）岩川雄幸・石塚和裕・井上輝一郎（1984）七ノキ林の地表 侵食-枝下高の違いが地表侵食に及ぼす影響. 昭和 58 年度 林試四国支年報: 22-23.

6）環境省（2016）特定鳥獣保護・管理計画作成のためのガイ ドライン（ニホンジカ編・平成 27 年度）。環境省自然環境
局野生生物課鳥獣保護管理室, $84 \mathrm{pp}$.

7）川口武雄 - 滝口喜代志（1957）山地土㙵侵蝕の研究 （第 3 報）地被物の侵蝕防止機能に関する実験。林業試験場研究 報告, 95: 91-124.

8）気象庁（2002）メッシュ気候值 2000. 気象業務支援センタ 一, CD-ROM.

9）北原 曜 (2002) 植生の表面侵食防止機能. 砂防学会誌, 54(5): 92-101.

10）三重県 (2007) 特定鳥獣保護管理計画（ニホンジカ）（第 2 期）.三重県, $25 \mathrm{pp}$.

11）三浦 覚 (2000) 表層土壤における雨滴侵食保護の視点か らみた林床被覆の定義とこれに基づく林床被覆率の実態評 価. 日本林学会誌, 82(2): 132-140.

12) Miura, S., Hirai, K., Yamada, T. (2002) Transport rates of surface materials on steep forested slopes induced by raindrop splash erosion. Journal of Forest Research, 7(4): 201-211.

13）中森由美子・㴰井忠人・三浦 覚 (2012) 急傾斜ヒノキ人 工林における伐採方法の違いによる細土, 土砂, リター移 動量の変化. 日本森林学会誌, 94(3): 120-126.

14）沼本晋也 - 渥美功介 - 野々田稔郎 - 武井量宏 - 近藤観慈 林 拙郎・島田博匡 (2007) 強度間伐ヒノキ人工林におけ る水・土砂動態-三重県白山町内ヒノキ林における間伐処理 後の変化-. 中部森林研究, 55: 161-164.

15）島田博匡（2006）ヒノキ人工林の林床における強度間伐後 2 年間の木本種動態. 三重県科学技術振興センター林業研 究部研究報告, 18: 1-12.

16）島田博匡（2007）ウラジロに覆われた再造林放棄地内の坪 刈地に植栽したヒノキに対するシカ食害. 日本緑化工学会 誌, 33(1): 122-127.

17）島田博匡・野々田稔郎（2009）針葉樹人工林における強度 間伐後の広葉樹侵入に及ぼすシカ採食の影響. 日本森林学 会誌, 91(1): 46-50.

18）山本一清. (更新： 2005 年 2 月 22 日) “LIA for Win32 (LIA32)”. 名古屋大学大学院生命農学研究科ホームページ. http://www.agr.nagoya-u.ac.jp/ shinkan/LIA32/index.ht $\mathrm{ml}$ (参照: 2006 年 3 月 23 日).

19）山瀬敬太郎・栃本大介 - 関岡裕明 - 藤堂千景（2010）間伐 木を利用した筋工による森林表土の流亡抑制. 日本緑化工 学会誌, 36(1): 9-14.

(2016 年 6 月 14 日受理) 